\title{
INCIDENCE OF ANTI-TOXOPLASMA ANTIBODIES IN WOMEN WITH HIGH-RISK PREGNANCY AND HABITUAL ABORTIONS
}

\author{
Maria de la Luz Galván Ramírez, Juan Luis Soto Mancilla, \\ Oscar Velasco Castrejón and Roberto Pérez Medina
}

\begin{abstract}
Toxoplasmosis is a zoonosis caused by Toxoplasma gondii, an obligate intracellular parasite. In pregnant women on the worldwide scale, there are seroprevalences from $7 \%$ to $51.3 \%$ and in women with abnormal pregnancies and abortions the seroprevalences vary from $17.5 \%$ to $52.3 \%$. In Mexico, seropositivity bas been found to vary from $18.2 \%$ to $44.8 \%$ in women with abnormal deliveries or abortions. This study's aim was to determine the incidence of IgG and IgM anti-Toxoplasma antibodies in women at the Gineco-Obstetrics Hospital of the Western Medical Center of the Mexican Social Security Institute. Three bundred and fifty women with high-risk pregnancies were studied, and 122 (34.9\%) were found to be IgG seropositive and 76 (20.7\%) were IgM positive. In one group of women with babitual abortions there were 48 (44.9\%) with the presence of IgG antibodies and 33 (33.3\%) were IgM seropositive. Seropositivity was analyzed according to age, occupation, socio-economic level, eating raw or poorly cooked meat, and living with cats.
\end{abstract}

Key-words: Toxoplasmosis. High-risk pregnancy. Habitual abortion.

Toxoplasmosis is a zoonosis caused by Toxoplasma gondii, an obligate intracellular parasite that infects all the cells and tissues in the vertebrae except the erythrocytes ${ }^{26}{ }^{30}$. There are five different ways, humans can contract the infection: ingesting oocysts in foods contaminated by cat feces: ingesting cysts in tissues of poorly cooked meat, transplacental route blood transfusions and organ transplants ${ }^{3}$ ${ }_{28}{ }^{30}$. The sub-clinical infection in humans is very common although there are great differences depending on the geographic areas, as indicated by the prevalence of antibodies that range from $1 \%$ in Alaska to $90 \%$ in Paris ${ }^{41112}$. In Mexico rates from $22 \%$ to $47 \%$ have been found through the positivity of Sabin and Feldman positivity test, and by intradermoreaction. It was confirmed that between $15 \%$ to $65 \%$ of the population has been exposed to $T$. gondi $i^{1}$. In 1966 Roch

Centro de Docencia, Investigación y Diagnóstico de Enfermedades Tropicales de la Universidade de Guadalajara, Mexico.

Address to: $\mathrm{Dr}^{\mathrm{a}} \mathrm{M}^{\mathrm{a}}$ de la Luz Galván Ramírez. Centro de Docencia, Investigación y Diagnóstico de Enfermedades Tropicales de la Universidad de Guadalajara. Lago Camécuaro \#2398 Colonia Lagos del Country. CP: 44177 Guadalajara, Jalisco, Mexico. Phone: (9136) 53-0880, Fax: (9136) 17-9935.

Recebido para publicação em 14/10/95. reported 30\% $\%^{24}$; in 1992 Velasco, using indirect immunofluorescence with 1:128 dilution, found that out of 29,935 cases in the general population there was an average of $50 \%$ seropositivity. These rates varied according to geographic area, from $17.1 \%$ in the southern part of the state of Baja California, located in the northern zone of Mexico, to $67.5 \%$ in the state of Tabasco in the southern zone, and in the state of Jalisco $36.2 \%$. On the worldwide scale, there are seroprevalences in pregnant women that range from $7 \%$ to $51.3 \%$, and in women who have had abortions, they range from $17.5 \%$ to $52.3 \% 12378910111317182030$. In Mexico seropositivities of $18.2 \%, 19 \%$ and $30 \%$ have been reported in women with abnormal deliveries or abortions, and, out of these, $34.5 \%$ of the children have been affected at bitth $^{5} 111519232527$. However, the most recent research in the state of Yucatán indicates figures of $44.8 \%$ for habitual abortions and $49.01 \%$ for spontaneous abortions ${ }^{27}{ }^{31}$. $\mathrm{n}$ the state of Jalisco, the incidence of IgG and IgM anti-Toxoplasma antibodies in women with high-risk pregnancies and habitual abortion was unknown. For this reason, this study's aim was to determine the incidence of anti- $T$. gondii antibodies in this group of women at the Gyneco-Obstetrics Hospital of the Western Medical Center of the Mexican Social Security 
Galván RML, Mancilla JLS, Castrejón OV, Medina RP. Incidence of anti-Toxoplasma antibodies in women with bigh-risk pregnancy and habitual abortions. Revista da Sociedade Brasileira de Medicina Tropical 28:333337, out-dez, 1995.

Institute, as well as finding out the relation seropositivity with age, occupation, socioeconomic level, and some risk factors such as eating raw or poorly cooked meat and living with cats.

\section{MATERIALS AND METHODS}

Groups. Five hundred and five blood sera were included in the study, of which 350 belonged to women with high-risk pregnancies (HR), 105 with habitual abortion (HA), and as a control (C), 50 sera were included from healthy women who were not pregnant or had not had abortions. An immunoenzymatic assay, IgG and IgM Toxonóstika ELISA from the Organón Teknika Company determined the presence of antiToxoplasma antibodies ${ }^{29}$.

Questionnaire. The following factors were taken into account: age, occupation, socioeconomic and educational levels, eating raw or poorly cooked meat, living with cats.

Statistical analysis. The mean, the standard deviation, and the correlation of the variables studied associated with sero-positivity were estimated.

\section{RESULTS}

By using the ELISA method to detect antiToxoplasma antibodies on the 505 women studied, the following results were obtained: in the HR group,122/350 (34.9\%) were found IgG positive and $76 / 350(20.7 \%)$ were IgM positive. In the HA group, 48/105 (44.9\%) were IgG positive and 35/105 (33.3\%) were IgM positive; in the $\mathrm{C}$ group, $13 / 50(26.01 \%)$ were $\mathrm{IgG}$ positive and $1 / 50(1.9 \%)$ were IgM positive. There was a significant difference $(\mathrm{p}<0.05)$ between the HA group and the other two groups. In regard to the trimesters of pregnancy, for the HR group during the first trimester of pregnancy there were $12 / 350$ $3.42 \%$ IgG seropositive, $4 / 350(1.14 \%)$ IgM positive; in the second trimester $34 / 350(9.7 \%)$ were IgG positive and 25/350 (7.1\%) were IgM positive; in the third trimester of pregnancy $75 / 350(21.4 \%)$ were IgG positive and $41 / 350$ $(11.7 \%)$ were IgM positive. In the HA group, there were 51 pregnant women: in the first trimester of pregnancy $1 / 56(1.7 \%)$ were $\operatorname{IgG}$ positive and equal number were IgM positive; in the second trimester $9 / 56(16.0 \%)$ were $\operatorname{IgG}$ positive and $8 / 56$ (14.2\%) were IgM positive, and during the third trimester of pregnancy $10 / 56(17.8 \%)$ were $\operatorname{IgG}$ positive and $8 / 56$ (14.2\%) were IgM positive.

Table 1 - Seroprevalence of anti-Toxoplasma gondii antibodies by age.

\begin{tabular}{|c|c|c|c|c|c|c|c|c|c|}
\hline Age & Num & Hig & risk & Num & $\mathrm{Hab} a \mathrm{~b}$ & ortion & $\overline{\text { Nun }}$ & $\overline{C O}$ & \\
\hline & & $\% \operatorname{IgG}$ & $\% \operatorname{IgM}$ & & $\% \operatorname{IgG}$ & \%IgM & & $\%$ & olgM \\
\hline$<20$ & 49 & 32.7 & 10.2 & 3 & 33.3 & 33.3 & 0 & 0 & 0 \\
\hline $0-30$ & 197 & 34.5 & 23.4 & 40 & 37.5 & 20.0 & 20 & 9.5 & 0 \\
\hline$>30$ & 104 & 36.5 & 21.2 & 62 & 41.9 & 38.8 & 30 & 43.7 & 3.1 \\
\hline otal & 350 & & & 105 & & & 50 & & \\
\hline
\end{tabular}

The average age for these groups was: $\mathrm{HR}$, $26.4 \pm 6.0 ; \mathrm{HA}, 32.3 \pm 7$ and $\mathrm{C}, 31.7 \pm 7.1$. The seropositivity results increased in the three groups, except for women in the HA group from 20 to 30 years old (Table 1). The occupations of the women in the study groups showed the following distribution: in the HR group $70 \%$ were housewives, $4 \%$ were workers, $18.5 \%$ employees, $6.6 \%$ professionals; in the HA group $81.9 \%$ were housewives, $4.7 \%$ were workers, $7.5 \%$ employees, and $6.6 \%$ professionals; in group C $1.9 \%$ were housewives, $69 \%$ were employees, and $28.3 \%$ were professionals. The presence of antiToxoplasma antibodies in relation to each occupation is shown in Table 2 . In regard to socio-economic status in the HR group: $6.6 \%$ belonged to the high economic level, $46.1 \%$ to the middle economic level, and $47.3 \%$ to the lower economic level; in the HA group $6.6 \%$ belonged to the high level, $48.1 \%$ to the middle level, and $45.2 \%$ to the low level; in the $\mathrm{C}$ group $9.4 \%$ belonged to the high level and $90.6 \%$ to the middle level. The only significant difference found between high and low classes was for IgG antibodies. The distribution of the presence of anti-Toxoplasma antibodies is shown in Table 3. The average educational level according to years of study was $6.04 \pm 4.0$ in the HR group; in the HA group, $6.0 \pm 3.9$ and in the $\mathrm{C}$ group $8.2 \pm 0.7$. The seropositivity of the groups studied is shown in Table 4 . Of the three groups, there were $11 \%$ of the women in the HR group who admitted the habit of eating raw or insufficiently cooked meat, $22 \%$ in the HA group, and $15.8 \%$ in the $\mathrm{C}$ group; and there were $33.5 \%, 43.4 \%$, and $18.9 \%$, respectively, who informed to live with cats (Table 5). 
Galuán RML, Mancilla JLS, Castrejón OV, Medina RP. Incidence of anti-Toxoplasma antibodies in women with high-risk pregnancy and habitual abortions. Revista da Sociedade Brasileira de Medicina Tropical 28:333337, out-dez, 1995.

Table 2 - Seropretalence of anti-Toxoplasma gondii antibodies by occupation Occupation Num High risk Num Hab abortion Num Control

\begin{tabular}{|c|c|c|c|c|c|c|c|c|c|}
\hline & & $\% \lg G$ & $\% \operatorname{lgM}$ & & $\% \mathrm{IgG}$ & $\% \operatorname{lgM}$ & & $\% I g G$ & $\% \mathrm{IgM}$ \\
\hline Houservives & 251 & 37.4 & 21.1 & 86 & 43.2 & 29.1 & 1 & 100 & 0 \\
\hline Workers & 14 & 21.4 & 14.2 & 5 & 20.0 & 0 & 0 & 0 & 0 \\
\hline Employees & 64 & 32.8 & 19.0 & 7 & 28.5 & 42.8 & 36 & 37.8 & 5.4 \\
\hline Professionals & 2) & 19.0 & 38.0 & 7 & 28.5 & 57.2 & 13 & 40.0 & 0 \\
\hline Total & 350 & & & 105 & & & 50 & & \\
\hline
\end{tabular}

Table 3 - Seroprevalence of anti-Toxoplasma gondii antibodies by socio-economic level.

\begin{tabular}{|c|c|c|c|c|c|c|c|c|}
\hline \multirow{2}{*}{ Level } & \multirow[t]{2}{*}{ Num } & High risk & Num & \multicolumn{2}{|c|}{ Hab abortion } & \multirow[t]{2}{*}{ Num } & \multicolumn{2}{|c|}{ Control } \\
\hline & & $\%$ IgG \%IgM & & \%IgG & \%IgM & & $\% \operatorname{lgG}$ & $\%$ IgM \\
\hline Low & 170 & 40.520 .0 & 46 & 37.0 & 28.2 & 0 & 0 & 0 \\
\hline Middle & 157 & 31.821 .6 & 52 & 42.3 & 26.9 & 45 & 29.7 & 2.1 \\
\hline High & 23 & $13.0 \quad 21.7$ & 7 & 42.9 & 71.4 & 5 & 40.0 & 0 \\
\hline Total & 350 & & 105 & & & 50 & & \\
\hline
\end{tabular}

Table 4 - Seroprevalence of anti-Toxoplasma gondil antibodies by educational level.

\begin{tabular}{|c|c|c|c|c|c|c|c|}
\hline $\begin{array}{l}\text { Years of } \\
\text { study }\end{array}$ & Num & $\begin{array}{l}\text { High risk } \\
\% \text { IgG } \% \mathrm{IgM}\end{array}$ & Num & $\begin{array}{l}\text { Hab abortion } \\
\% \text { IgG } \% \text { IgM }\end{array}$ & Num & $\begin{array}{l}\text { Con } \\
\% \text { IgG }\end{array}$ & \\
\hline$<6$ & 185 & 38.421 .6 & 72 & $43.0 \quad 70.9$ & 0 & 0 & 0 \\
\hline $7-9$ & 110 & 38.220 .0 & 17 & 29.4 & 23 & 39.1 & 0 \\
\hline $10-12$ & 31 & 22.529 .0 & 12 & 41.6 & 13 & 38.4 & 0 \\
\hline$>12$ & 24 & 8.38 .3 & 4 & 75.0 & 14 & 18.7 & 0 \\
\hline otal & $350^{\circ}$ & & 105 & & 50 & & \\
\hline
\end{tabular}

Table 5 - Seroprevalence of anti-Toxoplasma gondii antibodies and risk factors.

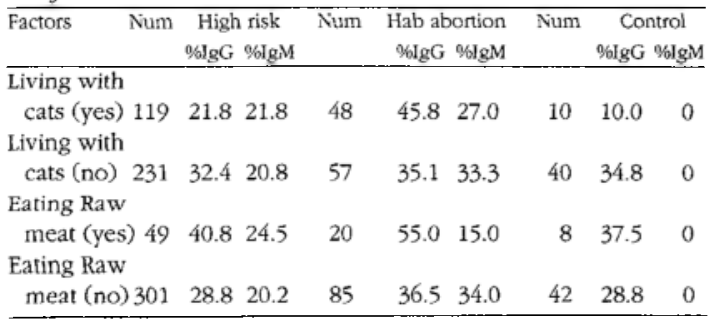

\section{DISCUSSION}

The results obtained showed that in the group of women with high-risk pregnancies, $34.9 \%$ had been exposed to T. gondii and $20.7 \%$ showed recent infection. The results are almost the same as those found in the general population in the state of Jalisco $36.2 \% \%^{28}$ and greater than the figures reported for Mexico City of $18.2 \%$ and $19 \%^{52}$. In the habitual abortion group there was a greater number of women $44.9 \%$ who had been exposed to $T$. gondii, and 33.3\% with recent infection. These results are similar to those reported in the state of Yucatan, which confirms ours in the state of
Jalisco, located in the coastal zone of Mexico; the prevalence is greater than in other states in open population. Like other authors ${ }^{1} 161831$ we believe there is a close relationship between abortion and toxoplasmosis.

The greatest incidence of IgG antibodies was found in the third trimester of pregnancy in the HR group with $21.4 \%$ and $11.7 \%$ with active infections, which shows a high risk of congenital infections that is perhaps greater than the $5.6 \%$ previously found ${ }^{13}$ is.

In the three groups, the seropositivity of IgG antibodies increased with age, indicating that the number of people who have been exposed to $T$. gondii increases in direct relation to the population's age ${ }^{1128}$ however, the number of IgM antibodies was $33.3 \%$ greater in those younger than 20 . When analysing profession, seropositivity for IgG anti-Toxoplasma antibodies was more frequent in women who were housewives, and the active infections were more common in laborers, although we cannot pinpoint its origin.

The low socio-economic level showed a higher incidence of IgG antibodies $40.5 \%$ for the HR group alone. These results support previous findings in this region of Mexico, where no differences were found between socio-economic level and seropositivity for IgG antibodies ${ }^{28}$; however, the HA group (42.9\%) and group $C(40.0 \%)$ had a higher incidence of active infections in the high class; the reason for these findings could not be determined due to the limited number of women belonging to the high class. Educational and socio-economic levels are interrelated variables; their behavior turned out to be similar.

In the HR group there was a higher incidence of seropositivity in women with the habit of eating raw or poorly cooked meat $40.8 \%, 24.5 \%$. The AH group had more active infections ( $34.0 \%)$. These results could be due to the fact that these women do not eat raw meat, but they perhaps consume vegetables irrigated with sewage water, which has also been found to be a transmission mechanism ${ }^{26}$ 28; however, this phenomenon could not be taken into account since this study did not include it as a variable.

The presence of IgG anti-Toxoplasma antibodies was $45.8 \%$ and $33.3 \%$ greater for 
Galván RML, Mancilla JLS, Castrejôn OV, Medina RP. Incidence of anti-Toxoplasma antibodies in women with bigh-risk pregnancy and babitual abortions. Revista da Sociedade Brasileira de Medicina Tropical 28:333337, out-dez, 1995.

recent infections in members of the HA group, and $34.8 \%$ in group $C$. The previous results may be accounted, not only by the fact of living with a cat, but also by the way in which the cat lives with the guest, which has been fully discussed by other authors ${ }^{214} 2628$

Due to the fact that the majority of Mexico's population consists of young people, particularly in Jalisco, where there is a greater female population, we believe that carrying out anti-Toxoplasma tests on women before and during pregnancy is of utmost importance, in order to avoid or curb serious outbreaks of congenital toxoplasmosis.

\section{RESUMEN}

La toxoplasmosis es una zoonosis causada por Toxoplasma gondii, parásito intracellular obligado, en mujeres embarazadas a nivel mundial existen seroprevalencias del $7 \%$ al $51.3 \%$ y mujeres con embarazos anormales y aborto varian desde $17.5 \%$ al 52.3\%. En México se ba referido seropositividad del $18.2 \%$ al $44.8 \%$ en mujeres con partos anormales ó abortos. El propósito de este trabajo consistió en determinar la frecuencia de anticuerpos antitoxoplasma IgG e IgM en mujeres del Hospital de Gineco Obstetricia del Centro Médico de Occidente del Instituto Mexicano del Seguro Social. Se estudiaron 350 mujeres con embarazo de alto riesgo encontrando 122 (34.9\%) seropositivas a IgG y 76 (20.7\%) a IgM, y en un grupo de 105 mujeres con aborto habitual resultando 48 (44.9\%) con presencia de anticuerpos IgG y 33 (33.3\%) a IgM. Se analizó la seropositividad con la edad, ocupación, nivel socioeconómicoa, ingesta de carne cruda ó mal cocida y contuivencia con gatos.

Palabras-claves: Toxoplasmosis. Embarazo de alto riesgo. Aborto babitual.

\section{ACKNOWLEDGEMENTS}

The authors would like to acknowledge $\mathrm{Dr}^{\mathrm{a}}$ Sylvia Sánchez for her technical assistence in the preparation of this paper.

\section{REFERENCES}

1. Abdel-Hafez SK, Shbeed I, Ismail NS,Abdel-Raham F. Serodiagnosis of Toxoplasma gondii in habitual aborting women and other adults from North Jordan. Folia Parasitology (Praha) 33:7-13,1986.

2. Aline S, Aluja AP. Estudio sobre la frecuencia del ooquiste de Toxoplasma gondii en el gato doméstico del Distrito Federal. Gaceta Médica de México 113:455-459,1977.

3. Al-Meshari AA, Chowdhury MNH, Chattopadhyay SK, De Silva SK. Screening for toxoplasmosis in pregnancy. International Journal of Gynecology and Obstetric 29:39-45,1989.

4. Biagi F. Datos actuales sobre biología y epidemiología de la toxoplasmosis. Gaceta Médica de México 111:165-167,1976.

5. Biagi F, Islas PM, González C. Frecuencia de la toxoplasmosis en relación al parto. Gaceta Médica de México 108:127-130,1974.

6. Clayton L, Miles HB. Toxoplasmosis and pregnancy. Australian and new Zealand Journal Obstetrics and Gynecology 30:32-33, 1990.

7. Daffos F, Forestier F, Capella P, Thulliez P, Aufrant $\mathrm{CH}$, Valenti D, Cox W. Prenatal management of 746 pregnancies at risk for congenital toxoplasmosis. New England Journal of Medicine 318:271-75, 1988.

8. Decavalas G, Papapetropoulou M, Ginnoulaki E, Tzigounis V, Kondakis XG. Prevalence of Toxoplasma gondii antibodies in gravidas and recently aborted women an study of risk factors. European Journal Epidemiology 6:223-226,1990.

9. Desmonts G, Courver S. Toxoplasmosis in pregnancy and its transmission to the fetus. Bulletin of New York Academy of Medicine 50:146-159, 1974.

10. Desmonts G, Courver S, Peupion JC. Un diagnostico precoce de la toxoplamose Aigue. Presse Medicale 1:339-341,1972.

11. Díaz O, Vaca M. Evolución y epidemiología de la toxoplasmosis. Revista Mexicana de Infectología 6:146-152,1985.

12. Feldman HA. Epidemiology of Toxoplasma. Epidemiology 4:204-214,1982.

13. Forsgren M, Gille E, Ljungstrom I, Nokes DJ. Toxoplasma gondii antibodies in pregnant women in Stockholm in 1969,1979, and 1987. Lancet 337:1413-1413,1991.

14. Frenkel JK. Toxoplasma in and around us. Bioscience 23:43,1973.

15. Galván ML, Garzón M. Estudio serológico en niños con toxoplasmosis. Revista Latinoamericana de Microbiología 31:267$270,1989$.

16. Johnson AM, Roberts H, Wetherall B, Mc Donald PJ, Need JA. Relationship between spontaneous abortion and presence of antibody to 
Galvän RML, Mancilla JLS, Castrejón OV, Medina RP. Incidence of anti-Toxoplasma antibodies in women with bigh-risk pregnancy and babitual abortions. Revista da Sociedade Brasileira de Medicina Tropical 28:333337, out-dez, 1995.

Toxoplasma gondii. Medical Journal of Australia 1:579-580,1979.

17. Langer H. Repeat congenital infection with Toxoplasma gondii. Obstetric and Gynecology 21:318,1965.

18. Meylan J. Toxoplasmosis as a cause of repeated abortion. Toxoplasmosis. Hans Huber Publisher, Vienna, 1971.

19. Molina PC, Ontiveros C, Uribe R. Investigación de anticuerpos contra el Toxoplasma gondii por medio de la inmunofluorescencia en mujeres con embarazos anormales. Salud Pública de México 31:27-39,1971.

20. Nakib AW, Ibrahim ME, Hathout $H$, Moussa MA Deverajan LV, Thoruburn $H$, Yousof AM. Seroepidemiology of viral and Toxoplasma infections during pregnancy among arab women of child bearing age in Kuwait. International Journal of Epidemiology 12:220-223,1983.

21. Remington JS, Desmonts G. Toxoplasmosis. In: Remington JS, Klein JO (eds) Infectious disease of the fetus and newborn infant. WB Saunders, Philadelphia 191:332,1976.

22. Remington JS, Miller MJ, Brownlee I. IgM antibodies in acute toxoplasmosis. II. Prevalence and significance in acquired cases. Journal of Laboratory and Clinical Medicine 71:855-866, 1968.

23. Roch E, Bravo BM. Incidencia de toxoplasmosis congénita en una nuestra de 2,186 recién nacidos vivos en la ciudad de México. Revista del Instituto de Salud Pública y Enfermedades Tropicales de México 22:221,1962.
24. Roch E, Varela G. Diversos aspectos de la investigación sobre toxoplasmosis en México, resultados de 29, 883 reacciones de Sabin y Feldman de 1953. Salud Pública de México 26:31, 1966.

25. Roch Ubiria E. La Toxoplasmosis Congénita, Problema Médico-Social. Salud Pública de México 18: 871-874, 1976.

26. Swarzber JE, Remington J. Trasmission of Toxoplasma. American Journal Disease Children 129:777-779, 1975.

27. Varela G, Roch E, Zavala J. Estudio sobre toxoplasmosis en México. Salud Pública de México 3:451-454, 1961.

28. Velasco O, Salvatierra J, Valdespino JL, Sedano AM, Galindo VS, Llausas A, Tapia CR, Gutierrez G, Sepúlveda J. Seroepidemiología de la toxoplasmosis en México. Salud Pública de México 34:222-229, 1991.

29. Verhofsted C. Van Renterghem JP. Comparison of six comercial enzyme linked immunosorbent assays for detecting IgM antibodies againt Toxoplasma gondii. Journal of Clinical Pathology 42 1285-1290, 1989.

30. Wong SY, Remington JS. Biology of Toxoplasma gondii. AIDS 7:299-316,1993.

31. Zavala VJ.Guzmán ME,Becerra PM, Rodríguez ME. Toxoplasmosis y aborto en pacientes del Hospital O'Horan de Mérida Yucatán. Salud Pública de México 31:664-668, 1989. 